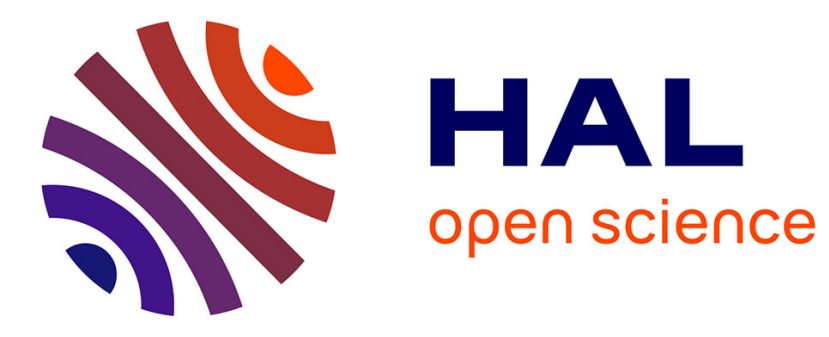

\title{
Mary Ward's English Institute: The Apostolate as Self-Affirmation?
}

Laurence Lux-Sterritt

\section{To cite this version:}

Laurence Lux-Sterritt. Mary Ward's English Institute: The Apostolate as Self-Affirmation?. Recusant History, 2006, 28 (2), pp. 192-208. hal-01060821

\section{HAL Id: hal-01060821 \\ https://hal.science/hal-01060821}

Submitted on 5 Sep 2014

HAL is a multi-disciplinary open access archive for the deposit and dissemination of scientific research documents, whether they are published or not. The documents may come from teaching and research institutions in France or abroad, or from public or private research centers.
L'archive ouverte pluridisciplinaire HAL, est destinée au dépôt et à la diffusion de documents scientifiques de niveau recherche, publiés ou non, émanant des établissements d'enseignement et de recherche français ou étrangers, des laboratoires publics ou privés. 


\section{MARY WARD'S ENGLISH INSTITUTE: THE APOSTOLATE AS SELF-AFFIRMATION?}

\section{Laurence LUX-STERRITT}

\author{
LERMA (E. A. 853), Aix-Marseille Université
}

Mary Ward (1585-1645) is known as the foundress of the Institute of the Blessed Virgin Mary, an Order of women which continues to educate thousands of girls around the world. During the first decades of the seventeenth-century, her foundation was a religious venture which aimed to transform the Catholic mission of recovery into one that catered for women as well as men. It maintained clandestine satellites on English soil and opened colleges on the Continent, in towns such as St Omer (1611), Liège (1616), Cologne and Trier (1620-1), Rome (1622), Naples and Perugia (1623), Munich and Vienna (1627) and Pressburg and Prague (1628). There, it trained its own members and undertook the education of externs and boarders. The Institute's vocation was not only to maintain the faith where it was already present but also to propagate it; as such, it went far beyond the accepted sphere of the feminine apostolate and its members were often labelled as rebels who strove to shake off the shackles of post-Tridentine religious life. To some modern historians, Mary Ward was an 'unattached, roving, adventurous feminist'; to others, she was a foundress whose initiative deliberately set out to lay tradition to rest and begin a new era for the women in the Church. ${ }^{1}$

Yet, this study will contend that the English Ladies' active vocation did not imply any disdain towards long-established forms of female religious life. A timely reassessment of the Institute's spirituality indicates that, when they denied themselves the perfect life of the cloister, the raptures of contemplation and the spiritual conduit of conventual life, these missionaries embraced the apostolate, not as a gesture of selfempowerment but as one of self-abnegation in the service of the Church.

\section{An Ignatian Institute for missionary women}

When, in 1621, Mary Ward wrote the Plan known as the Institutum, she described her English Ladies as combatants, working alongside priests for the conversion of Protestants. In this document, which she submitted to Rome in her quest for papal approval, the military metaphor was omnipresent, portraying the Ladies as soldiers in battle, perhaps, even, on a crusade which would tax their physical and spiritual resources to their limits. They followed a vocation that had a deeply missionary trend running at its very core. She warned postulants to consider their position most carefully since, as she put it:

\footnotetext{
Whoever wishes to serve beneath the banner of the cross as a soldier of God in our Society, which we desire to be designated by the name of Jesus', is a member of a Society founded primarily for this purpose: to strive for the defence and propagation of the faith and for the progress of souls in Christian life and doctrine, leading them back from heresy and evil ways to the faith, to a Christian manner of life. ${ }^{2}$
}

In this Plan, Ward revealed her vision of an international mission shaped on Society of Jesus, pursuing the same goals, functioning with the same structures and even bearing the same name. Borrowing her military imagery from the Jesuit lexicon, 
Ward praised her followers as 'soldiers of God' serving God 'beneath the banner of the cross'. She exposed both her faithful imitation of the Society and its desire to be recognised as its independent female counterpart. Unequivocally, she went so far as to request the right for her 'Society' to be 'designated by the name of Jesus'. Her military imagery was extended further when she declared: 'After they have enlisted through the inspiration of the Lord in the militia of Jesus Christ, they ought to be prompt in carrying out this obligation which is so great, being girded for battle day and night.' ${ }^{3}$ All in all, the Institute's vocation covered a much wider scope of action than that usually attributed to women, even in the circumstances of the English mission; its members did not only help Catholics but also worked towards the conversion of Protestants in an assertive manner.

The Institute was unorthodox in that it claimed to give women some of the responsibilities which had, thus far, been the preserve of the clerical men; such ambitions were expressed in the Institutum, where the Ladies vowed to take their mission beyond Northern Europe (where they were already settled) and to obey the pope should he send them 'among the Turks or any other infidels, even those who live in the region called the Indies, or among any heretics whatever'. ${ }^{4}$ Crucially, this clause opened the English Ladies' vocation to a world-wide level, including them in the Counter Reformation's drive of recovery alongside male priests. This desire to be involved in the global Catholic mission, however, was to remain purely a theoretical statement, since the pontiff never deemed it fit to dispatch female proselytisers on such an operation.

Despite claims to a universal evangelical brief, it was in their more local endeavours in the English mission that Mary Ward and her followers represented the most direct threat to the established status quo of post-Tridentine female religious life. There, their clandestine networks allowed them to work daily as missionaries without the decency of enclosure or the supervision of a male ordinary. Running parallel to the first organised houses in London and later, in the North of the country, smaller pockets of work allowed the Institute to penetrate the fabric of English society in a discreet and covert way. In areas where setting up a school was not possible, some members worked as single, anonymous individuals, often living with a family under the guise of a member of the household. The narrative of Sister Dorothea, of whom we know nothing except that she was one of the lay members working in England, showed how she not only catered for existing recusants, but also converted Protestants. She spent a large proportion of her time helping the poor, caring for them in their sickness and generally doing good works. Although she was not in a position to open schools, she honoured her educational vocation by teaching children at home. Yet, her report conveys little information regarding the contents of her curriculum or even her pedagogical methods. Significantly, she chose to focus on her missionary work of conversion in her report, and she described her activities as a proselytizer in considerable detail.

By teaching her pupils within their own homes, Dorothea established contact with important families and found opportunities to converse with them about religious matters. In those times of anti-Catholic persecution, many were not entirely ready to commit to recusancy, for fear of the consequences. She applied herself to the pastoral service of such households, thereby gradually persuading them not to attend Anglican services regularly, or at least to refrain from communion there. Furthermore, she strove to alienate conforming families from the Church of England, persuading them not to attend Anglican services as regularly, or at least to refrain from communion there. ${ }^{5}$ She brought about the conversions of nine people, but encountered difficulties 
officially to receive these new converts into the Church: she often had to walk miles on foot to meet with the nearest priest, or even wait for months before she could secure one. ${ }^{6}$ Her function complemented that of the clergy; though she could not dispense the sacraments herself, her work in Suffolk was of a missionary nature and, clearly, transcended early-modern conceptions of womanly religious roles.

Success as a Catholic evangelizer brought Sister Dorothea to the notice of Protestant authorities: the church court issued a sentence of excommunication and it was only her care in preserving her anonymity that saved her in this crisis. Since villagers and officials knew her simply as 'Dorothy', the absence of a family name prevented the local minister from taking any further action. However, the immediacy of danger in her missionary occupations did not dampen her spirits for long and she soon resumed her activities right under the very noses of her prosecutors. This anecdote shows how individual members of the Institute worked in England in a manner entirely comparable with that of missionary priests. Although Sister Dorothea could not herself reconcile people to the Church, she played a crucial role in converting and instructing them until she could procure a priest who could officialise their conversion. Her skill and her dedication to the cause actually returned souls to the Catholic Church and prepared the ground for many missionary priests.

Indeed, Dorothea underlined the complementary nature of her work with that of the priests. At a time when clerical ranks were divided about the 'Jesuitesses', she found that, on English soil, she could work hand in hand with missionaries and enjoy mutual support in their alliance in the common cause of the Church. She took upon her the religious instruction of the new converts and ensured that their new-found faith was solidly anchored. Though she could not dispense the sacraments herself, her work in Suffolk was obviously of an active missionary nature, and therefore transcended early-modern conceptions of womanly religious roles.

Sister Dorothea's account illustrates the kind of tasks that were to lead to the Institute's condemnation in 1631. Indeed, the work of the English Ladies was not taking place within the established forum of religious enclosure; their teaching and catechising activities were the result of a self-motivated and independent enterprise that functioned outside the control of the episcopate and outside the secluded, private sphere of conventual classrooms. Thus, their physical freedom actually worked against their ultimate success as an institution. It was because the Ladies catechised outside the traditional female arena of the enclosed classroom that their endeavours were categorised as public preaching contravening the Decrees of Trent and the Pauline injunctions for women to remain silent in matters of religion. As they outgrew the sphere of humble domestic maintainers of the faith, they became involved in works of conversion that were deemed highly unsuitable for women in seventeenth-century Europe.

One of Mary Ward's most famous declarations was her reply to a remark made by a Jesuit who doubted the constancy of those he called 'but women'. In her often-quoted retort, Ward addressed her congregation of St Omer in a manner that sounds assertive even to the modern reader:

There is no such difference between men and women, that women may not do great matters, as we have seen by the example of many Saints who have done great things, and I hope in God it will be seen that women in time to come will do much. ${ }^{7}$

Her defence of women as worthy beings thus showed that she did not share the patriarchal view generally endorsed by the early modern Church. The next passage demonstrates this even further: 
What think you of this word, 'but women'? If we were in all things inferior to some other creature, which I suppose to be men, which I care be bold to say is a lie then, with respect to the good Father, I may say: it is an error. [...] I would to God that all men would understand this verity: that women, if they will, may be perfect, and if they would not make us believe we can do nothing, and that we are but women, we might do great matters. ${ }^{8}$

These words speak for themselves: Ward did not share her contemporaries' conceptions of women. Her strength of conviction, combined perhaps with her failings in the art of diplomacy, surely made it plain in her rapport with the authorities that she refused to comply with female role-definitions. Her defence of the value of women in the active ranks of the Church patently disregarded centuries of tradition that deemed them to be physically, morally and spiritually weaker than men.

Although there is no evidence that the Roman Curia ever heard or read these speeches directly, there can be little doubt that, in their dealings with Mary Ward, they became familiar at least with their spirit. In the 1621 Memorial of the English clergy, John Bennet (the agent for the secular clergy in Rome) accused her of pride and immodesty, declaring that she and her Ladies 'presume [d] of their own power that it is omnipotent'. Many supported this view and felt equally angered by Mary Ward's refusal of traditional enclosure. In the same year as Colleton expressed his suspicions, Fr. John Bennet, (d. 1623) the agent for the English secularError! Bookmark not defined. clergy in Rome, wrote: 'Briefly closure they must embrace, and some Order already approved, or else dissolve. But of closure they will not hear.' ${ }^{10}$ Some years later, in 1630, Francesco Ingoli, secretary of Propaganda Fide, wrote along the same lines. In his Compendium of the process made by the Nuncio of Cologne against the Jesuitesses in the year 1630 and month September he described the Institute as 'a new form of religious life without the license of the Apostolic See, [...] without enclosure, against the pontifical bulls'. After marring the Ladies' honour by equating their geographical mobility with loose morals, he denounced their impudence since, he claimed, they preached publicly, taught theology and dared to think themselves equal to priests. ${ }^{11}$

These were women without a custos, who brazenly refused male supervision and the propriety of the cloister; they were given the sarcastic sobriquets of 'galloping girls' or 'wandering nuns'. ${ }^{12}$ As the 1631 Bull of suppression proved, the Institute's adopted lifestyle (missionary, unenclosed and autonomous) was simply unacceptable to the Church of the seventeenth century. Yet Mary Ward championed her ideal of a female counterpart to the Society of Jesus, which she had no intention to depart from in any way. ${ }^{13}$ But did her unwillingness to compromise on the terms of her mission spring from her assertive resolution to empower women within the Church? Did she envisage her Institute as defined by gender, striving to liberate women from the perceived yoke of patriarchal dictates? 


\section{The cloister within the soul}

Careful study of the Institute's documents reveals that, when Mary Ward was but a child, her initial vocation was of an introspective nature; only gradually did it evolve towards exteriorisation. ${ }^{14}$ Between 1600 and 1606, at Osgodby (East Riding), the seat of the prominent Yorkshire recusants Lady Grace and Sir Ralf Babthorpe, she was introduced to the quasi-religious lifestyle observed by the family and its servants. ${ }^{15}$ In a conscious attempt to imitate the regularity of conventual offices, the Babthorpes' monastic-like regularity observed a daily horarium that prompted their ministering priest, James Sharpe, (alias Pollard, 1577-1630) to consider the house like a monastery. ${ }^{16}$ On working days, he said two morning Masses, one for the servants at six o'clock and the other at eight o'clock for those who did not attend the first. Every afternoon, at four o'clock, he said vespers and compline for the gentry members of the household. On Sundays and holy days, the doors were locked while the members of the household heard Mass and sermons and the children were later taught catechism. The locking of the doors before the service, although primarily a practical precaution, symbolized on a metaphorical level the mental shutting out of the world during times devoted to contemplation. Moreover, most members of the Babthorpe family meditated and prayed daily, following the Spiritual Exercises and retiring to bed at nine o'clock after their evening litanies; the family's spirituality was further enhanced by fortnightly confession and communion.

It is arguable that English recusants separated from the control of their Church, far from seizing the opportunity to innovate and escape the strict regime of monastic observance were, on the contrary, compelled by adverse conditions to adhere to tradition with renewed devotion. Since they had been deprived of their freedom of worship, recusant households had turned inwards, in order to cultivate traditional contemplation and imitate the monastic model of the 'perfect' life as faithfully as their daily occupations in England allowed. As a recusant girl staying with the Babthorpe family, Mary Ward had found personal ways of bringing the aura of the cloister into her secular time and space; on the one hand, she allocated a cardinal virtue to each day of the week whilst, on the other, she dedicated each room to a particular saint. Her desire, in those early years, was to enter a convent on the Continent, where she could take the habit and become a nun, consecrating her every waking moment to contemplation, prayer and meditation.

Her six-year stay at Osgodby deeply influenced the awakening of her vocation; she became imbued with the empirical experience of its quasi-monastic regularity and lived through events that were to become important milestones in the development of her early spirituality. For instance, it was as the women were gathered together, sewing or embroidering, that she heard the story of a nun who, after breaking her vow of chastity and giving birth to a child, had been allowed to reenter her community. ${ }^{17}$ However, the offender was to be constantly punished for her sin: she was to lie before the chapel door so that all the other nuns stepped over her on their way to the choir. On hearing the story, Mary Ward was not shocked by such treatment but, on the contrary, edified by its example; of these early days, she later remembered: 'Of all virtues to which I was drawn with greatest affection was chastity'. ${ }^{18}$

This respect for virginal purity remained a constant trait of her spirituality throughout her life. Thus, in the 1612 Schola Beatae Mariae, Mary Ward addressed the education of girls by endorsing the received ideal of feminine perfection. Pupils were exhorted to behave as models of proper social behaviour, to 'curb passions, 
restrict inordinate desires, obey parents, turn away from the levity of girls; observe virginal maturity' and show restraint at all times. ${ }^{19}$ In fact, the Institute's teaching retained elements of a traditional nature and inculcated the virtues advocated by the patriarchal consensus of the period as intrinsically feminine. The qualities of reserve and discretion should become second nature in a pupil, in order to prevail against curiosity and gossip - two faults believed to be particularly recurrent in young females. More importantly, the triumvirate of the most holy virtues in women, chastity, humility and obedience, was praised and recommended daily, as the crown on a virtuous wife's head.

This conformist outlook was consolidated when four years later, the 1616 Ratio Instituti specified that the members of the Institute should take a private vow of chastity, the transgression of which would incur irrevocable expulsion, regardless of circumstances. It was the only instance of a sin deemed grave enough to warrant the exclusion of a member: the English Ladies would be of irreproachable moral purity and 'altogether angelical'. ${ }^{20}$

As a young woman, Mary Ward's ideal of devout perfection endorsed all the canons of the post- Tridentine Church. In fact, when she first left England to enter religion in 1606, she had elected to become a Poor Clare, a choice which expressed a spirituality centred on inner reflection. As she later confessed, she could not, as yet, envisage a religious purpose outside the traditional cloister. She explained that, initially, she had felt drawn to monasticism and anticipated 'content in solitude and abstraction from the world'. She expanded:

I had no particular vocation to one Order more than another, only it seemed to me most perfect to take the most austere that a soul might give herself to God, not in part but altogether since I saw not how a religious woman could do good to more than herself alone. To teach children seemed then too much distraction [...] as therefore to hinder that quiet and continual communication with God which strict enclosure afforded. ${ }^{21}$

Although the Institute was deemed so objectionable that it had to be suppressed by Urban VIII in 1631, and although Mary Ward herself is sometimes seen as a feminist activist, she had begun her religious journey in a remarkably unthreatening way, holding traditional virtues as her ideals of perfection.

The foundress shared this spiritual heritage with her closest followers: the necrology of Barbara Babthorpe (1591- 1654) maintained that 'her spiritual gifts far surpassed her natural talents, though these were of a very high order', which suggests that she may not have felt talented or even drawn to a teaching apostolate, and may have preferred more traditional avenues of communication with the divine through contemplation and prayer. Although reputedly 'severe and hard, unmerciful even to herself', her rigid self-discipline was counterbalanced in her kindness to others and impartial government. ${ }^{22}$

Another pillar of the Institute, Winifred Wigmore (1594-1656), was known by her sisters as 'the little Saint', in honour of her fair and sweet temper. Her eulogist equally praised her high degree of piety. ${ }^{23}$ Her life was characterized by her meekness and extreme personal poverty, and by her self-effacing dedication of her time and possessions to the well-being of others. Through the example of these sisters, who shared Mary Ward's inclination towards contemplation and her respect for recognized monastic values, it becomes clear that the Institute, despite its active nature, aspired to some of the more traditionally monastic ideals. In fact, its members combined their new way of life with the observance of many traits of medieval religious practice. 
One of the most telling attestations of Ward's faithfulness to the conventual model was her early affinity with claustration and the contemplative channels it offered; paradoxically - since it was her steadfast refusal of enclosure that led to the suppression of her Institute - she started her project with a semi-cloistered way of life, which she described in her 1612 Schola Beatae Mariae:

\begin{abstract}
And although this Institute of its nature does not allow of the strict cloister in the present condition of England, still, far from having the house open to all, we desire rather to have cloister so strictly observed that no access is to be allowed to any extern whatsoever in the Chapel and [boarding] schools $[\ldots]$. But necessary and serious conversations will be referred to the grille destined for that purpose. $^{24}$
\end{abstract}

This passage plainly indicated that, in 1612, Ward expected her Institute to compensate for its lack of strict enclosure by implementing some safeguards to guarantee the integrity of the religious house and of its boarding school. Clearly, what was to become a ground-breaking vocation had in fact originated from traditional beginnings, embracing most of the received conceptions of female religious perfection.

In that sense, the Institute's archives contradict the stereotype of a rogue community of women intent on divorcing themselves from centuries of tradition. Rebellious natures do not emphasise obedience as one their chief spiritual aims; yet, as Mary Ward took the Spiritual Exercises, she repeatedly promised to subject her own will to that of her director. The 35 resolutions which she took around 16121614: revealed her love for the established notions of medieval monasticism. In resolution 10, she plainly declared: 'I will never contradict in desire, word, nor action the will of my superior'. Her determination was reiterated several times throughout the text and, at times, gained an almost ascetic tone:

I will not permit in myself the least repugnance to whatsoever obedience shall ordain, nor nourish in myself a contrary opinion. My will with obedience shall be always one and the same in every occasion, whether the thing be great or small, prosperous or adverse, easy or hard. ${ }^{25}$

In this way, Mary Ward applied herself to the pursuit of spiritual perfection through the channels of monastic values such as chastity, separation from the world and obedience. She and her English Ladies were far from rejecting the established paradigm of religious excellence; on the contrary, they strove towards its complete assimilation and regarded it as the only sound foundation on which to base their novel foray into the female apostolate.

Moreover, although the Institute's rules exonerated its members from physical acts of penance which, by weakening the body, ran counter to the mission of the 'soldiers of God', many English Ladies remained attached to such traditional practices. Since, in England, she was forced to dress according to her social status to avoid detection, Mary Ward resolved to wear a hair shirt underneath her apparel, thereby practising asceticism even in the midst of English gentle society. In the same spirit of attrition she ate but one meal a day for the first seven years of her foundation and slept exclusively on straw beds, 'as a means to obtain light' ${ }^{26}$ Her resolve to punish her senses was also apparent in the resolutions she took during the Spiritual Exercises, and in which she pledged: 'Seeing that my loathness to suffer has been the cause of so many evils, I propose henceforward to embrace all contrary things as due for my sins, and the part and portion which for myself I have chosen'. ${ }^{27}$ In these ways, the foundress did not shrink from punishing herself for all but the smaller 
defects, and her spirituality was imbued with a trend of asceticism worthy of the most austere regular Orders.

Some years later, in 1618, Mary Ward wrote down a few notes during a spiritual retreat she undertook when spending some time working on English soil; her desire to punish herself for her perceived shortcomings remained as present as ever in statements such as 'I wanted a sorrow', '[I] had some desire and resolution to begin a course of mortification'. ${ }^{28}$ Such forms of penance were not a requirement but rather the expression of her personal asceticism: her understanding of religious perfection implied the observance of strict religious rules. Ward's ascetic penchant was also shared by some other members of the Institute, such as Frances Bedingfield, whose necrology recorded that she had renounced all the vanities of the world by the age of fourteen and chastised her body through fasting and the regular use of chains and of the discipline. ${ }^{29}$

Such indications of a propensity towards monastic catharsis, although they are the exception rather than the norm, nevertheless appear in the Institute's documents with more regularity than might have been anticipated considering the novel, Ignatian nature of the Ladies' vocation. It is clear that the English Ladies' spirituality derived directly from that to which they had been habituated in English recusant circles. As members of one of the most pioneering female religious enterprises in early modern Europe, they nevertheless held monasticism and contemplation in high regard and did not envisage their Institute as a way of freeing themselves from the obligations of the cloister.

Mary Ward's recusant upbringing unquestionably had a considerable impact upon her ideal of perfection. Most revealingly, her spirituality, like that of so many of those working in the English mission to ensure the survival of Catholicism, abounded not only with notions of asceticism but with the ideal of martyrdom as means to achieve perfection. In an England where Catholics regularly were victims of searches, fines, trials, imprisonment and even execution, recusancy was inextricably intertwined with martyrdom. Therefore, from a young age, Mary Ward had grown accustomed to the violence of religious persecution and viewed self-sacrifice as a necessary means for the attainment of sanctity. In her formative years, she considered dying for her faith to be one of the most perfect ways - if not the most perfect - to achieve sanctification in the eyes of God.

The tenth panel of Ward's pictorial biography, the Painted Life, offered a vivid illustration, recalling how at the age of sixteen, inspired by the lives of the holy martyrs, she had felt strongly attracted to martyrdom herself. She stands in the centre of the picture with, at her feet, traditional symbols of martyrdom such as knives, axes, spears and various instruments of torture. To her left, Catholics are put to death, their executions shown at the various stages of hanging, burning, disembowelling and quartering. As she literally embraces the gallows with both arms, she looks upon the scene with visible longing. This is highly reminiscent of the missionary outlook illustrated in the dramatic paintings of the English College of Douai. Yet, a small panel on the top right-hand corner of the picture offers a sharp contrast to the horror of the main scene: there, the young woman appears alone, facing a single majestic candle, absorbed in prayer, in an evocation of the revelation in which she understood that God required spiritual rather than bodily sacrifice. ${ }^{30}$ At this juncture, her spirituality became one in which ideals of martyrdom or of extreme asceticism were replaced by a deep concern for the spiritual welfare of others. The hardship to be endured would derive from her vocation to serve her neighbour through education, catechesis and apostolic works. 


\section{The apostolate as self-sacrifice}

There can be no doubt that the Institute, for all the novelties it entailed, nevertheless embraced many of the characteristics of traditional monasticism; what is more relevant is that it did not do so out of a sense of duty or obligation, but because its foundress deeply believed in the intrinsic value of the 'perfect' life. Though Mary Ward refused enclosure, she often expressed her admiration for religious claustration as a preserver of spiritual serenity and order; though she opted for the apostolate, she revered contemplation as a privileged path towards the divine and an efficient way to advance catholic progress in Europe. In this respect, our modern understanding of the relationship between action and contemplation contributes to the current sense of puzzlement over active communities' esteem for monastic values, which we see as paradoxical.

Since cloistered meditation has all but disappeared from our lifestyles, physical isolation and immobility have, on the whole, come to represent passivity and inactivity, which the twenty-first century is quick to dismiss as useless. Subconsciously shaped by today's values, equating action with empowerment and contemplation with subjection, historians have misread these determined women who braved both public opinion and ecclesiastical censure in order to join unrecognised teaching communities. Their resolve is understood as the indicator of ambition, combined with a strong desire to chose a different option; their choice, it is surmised, must be the manifestation of their self-will, refusing to limit themselves to the genderdefined boundaries of post-Tridentine religious life. However, the modern dichotomy between action and contemplation can be deceptive. It is arguable that these earlymodern pioneers did not envisage the apostolate as a means of liberation from the Church, but as a gesture of ultimate sacrifice to it. Rather than a movement of feminist empowerment, freeing women from religious subjection, could the English Ladies' catechising mission be an act of self-denial? ? $^{31}$

When, in 1620, Mary Ward wrote to Mgr Albergati to explain her change from a preference of an austere enclosed order to that of a missionary ideal, she described a divine revelation she believed to have experienced in 1609. The vision, known as the vision of St Athanasius's day, intimated that contrary to her personal inclination, she was not destined to be an enclosed nun. In this epiphany, she recalled, joy and hope were intertwined with anxiety and foreboding:

\footnotetext{
To leave what I loved so much, [...] to expose myself to new labours, which then I saw to be very many; to incur the several censures of men, and the great oppositions which on all sides would happen [...] afflicted me exceedingly. Yet had I no power to will or wish any other than to expose myself to all these inconveniences, and put myself into God's hands with these uncertainties. ${ }^{32}$
}

In this passage, Mary Ward explained that God's summons had compelled her, almost against her will, to leave what she had described as perfect contentment in solitude and contemplation. However, she confessed to Mgr Albergati, she understood that her own personal inclinations had to be forsaken in order to obey God's commands.

In the aftermath of this episode, Ward became prey to many doubts; she was to leave her Poor Clares convent, but she was not sure what else she was meant to do. When reflecting upon what might be required of her, she could only envisage entering another convent, of a different Order: she debated with her confessor whether she should enter the Teresians, so convinced was she that her calling was to be monastic. As she waited for her path to become clearer, she left for England, where she spent 
some months working for the recusant community. It was while she was there that her mysticism manifested another vision; this, know as the Gloria vision, convinced her she was not to become a Teresian any more than a Poor Clare, and left her more confused than ever. She recorded:

[...] though in that instant of time my understanding was clearly convinced that the thing then put before me was truly good [...] and my will so possessed as left without power, then or ever after, to love or elect any contrary thing, yet to have still all denied me, and nothing proposed in particular seemed somewhat hard. ${ }^{33}$

Confronted with the realisation that she was not to become an enclosed religious, Mary Ward's despondency soon transformed into complete abandonment of her self into the hands of God; her will was resigned to embrace, not what she would personally prefer but what came to her from God, through her enlightenments. Eventually, the way in which she was to realise her divine purpose was revealed to her through the same channel of visionary experience when, in 1611, she received divine direction to 'Take the same of the Society'. ${ }^{34}$ This final revelation came to her as a relief, a 'comfort and strength' which changed her entire soul. Thereafter, her design for a community of English women took a new form: after years of indecision between the contemplative and the active life, she took a decisive turn towards the apostolate. Through this ultimate revelation, she understood that she was to found a Society of Jesus for women. In this way, the Ignatian Institute came into being when its foundress surrendered her own will to obey that of God. Far from being an expression of assertive rebellion, her action was one of self-denying trust.

In order to understand the nature of Mary Ward's Institute, the mystical elements of its genesis cannot be underestimated. Indeed, this radical female Order not only pointed out the inadequacies of post-Tridentine religious life but also presumed to bridge the divide between the sexes in the Church. Such a militant challenge understandably seems revolutionary, intent on the demise of the old order and driven by the wilful ambition of a determined, charismatic leader. Yet, one must avoid the pitfalls of textual blindness and consider the creation of the Institute in context: Mary Ward never claimed to be the source of her Ignatian project. Personally, she felt drawn to the cloister and respected the Catholic tradition. When they embarked upon their mission, she and her followers were not indulging their own whim but rather sacrificing themselves to fulfil the will of God. The foundress, as a mystic, was simply obeying the divine commandment to found a Society of Jesus for women.

Therefore, Mary Ward abandoned her preferred path to begin her female Society of Jesus; she turned down the pleasures of cloistered contemplation in order to undertake labours towards which she did not feel any particular affinity. Hence, the 1616 Ratio Instituti presented the English Ladies' educational work as their particular gift to God, an offering that could not be made by enclosed communities:

no one is, by the Institute, obliged to observe strict enclosure, or to wear a determined religious habit, or to perform external penances and austerities; [the English Ladies] are not called to a life in which they can devote themselves only to themselves; but that, having Divine Love alone in view, they are to prepare themselves to undertake any labour whatsoever in the education and instruction of virgins and young girls. ${ }^{35}$

The foundress was urging her followers to refrain from penitential practices that could hinder them from fulfilling their apostolic duties. Teaching was to take precedence over everything else, even the established practices of the 'perfect' life: it was their 
calling, it was what God commanded. Their educational vocation was an act of selfdenial per se. In that sense, the rebellious 'Jesuitesses' in fact demonstrated abnegation by renouncing the rewards of contemplative piety and undertaking works for the Christian education of girls. They offered a new interpretation of medieval asceticism born from the very spirit of the Catholic mission of recovery. By putting the spiritual welfare of others before their own and choosing what they believed to be the more arduous path, they were able to reconcile the principles of monastic asceticism with their novel Ignatian vocation.

Indeed, some members were said to have taught despite a natural, physical inclination to the contrary; in her death notice, Mary Clifton, for instance, was praised for her constant teaching efforts 'notwithstanding her delicacy'. ${ }^{36}$ Like many others, Clifton's initial intention was to enter a traditional convent; only later did she come to embrace the apostolic ideal of the Institute as a more perfect way to give herself entirely to what the greater glory of God. The active teaching of the so-called 'Jesuitesses' can therefore be construed as an act of self-denial undertaken as the ultimate sacrifice to God; it was, as the Institutum put it, 'a pathway to God'. ${ }^{37}$

Mary Ward always anticipated considerable opposition against her Ignatian project, but welcomed these difficulties 'with a great desire to suffer much and many crosses'. ${ }^{38}$ She embraced suffering in her willingness to sacrifice her whole being in the pursuit of her divine vocation:

\footnotetext{
I then offered myself to suffer with love and gladness whatsoever trouble and contrariety should happen in my doing of his will [...] presented that perchance there was some great trouble to happen about the Confirmation of our course, and with this I found a great and new love to this Institute and a near embracing or union of affection with it; I offered myself willingly to this difficulty, and besought our Lord with tears that he would give me grace to bear it. ${ }^{39}$
}

Hardship did little to deter her from an apostolate which she embraced as the most arduous path and a mirror image of the life of Christ himself. Thus, at the age of 33, Mary Ward was prepared to follow her imitation of Christ to its ultimate conclusion: she was ready to die, not for the salvation of her own soul only, but for that of her fellow Catholics. This desire was still present in 1621 when, on her way to Rome, to present the pope with the Institutum, she stopped at Loreto and 'took for her part and portion to labour and suffer for Christ, having lively represented [sic] to her the much she was to suffer'. ${ }^{40}$

The thirtieth panel of the Painted Life illustrates Mary Ward's complex spirituality explicitly, capturing her re-interpretation of the medieval notions of martyrdom and cloistered contemplative devotion and her understanding of the active apostolate as a better, more complete way to please God. This panel represents the moment when, in 1619, she understood that saving the souls of others would be a greater gift to God than offering Him her own soul in a convent or on the gallows. ${ }^{41}$ Kneeling to the right of the scene, she is looking upon three different types of protagonists. In the top left-hand corner, martyrs, in their death agonies, are sacrificing their lives for their faith. In striking contrast to the violence of such a scene, the right-hand corner of the painting depicts a group of male and female figures from various older established Orders, all deeply absorbed in prayer in the company of illustrious saints. ${ }^{42}$ However, it is the third party upon which Mary Ward is smiling, a motley gathering of pilgrims and simple people she evangelized by her teaching. The caption reads: 'In 1619, in St Omer, while Mary was fervently thanking God for the grace of her vocation, He revealed to her that to help to save souls is a far greater gift than the religious life or even than martyrdom itself. ${ }^{43}$ 
Mary Ward saw the ideal of the 'perfect' life as essentially centred on the self and focused upon personal salvation. Conversely, the paradigm of martyrdom with which she grew up emphasized the sanctification of the martyrs themselves. Ward therefore hoped that, since her Ladies' vocation was a calling whose altruistic nature used the channel of catechesis in order to save souls, the workers in such a noble enterprise could not fail to be favoured by God. In this way, their educational vocation reaped a double harvest. It bore immediate and visible fruit in the mission of Catholic recovery, improving its pupils' knowledge of God and enabling them to read spiritual works. Women who had been educated by the English Ladies were fully armed to face the hardships that awaited them in life, particularly if they returned to live under the repressive penal laws of England. Their training enabled them to remain steadfast in the faith, by the regular practice of the Ignatian Spiritual Exercises, mental prayer and sound doctrinal foundations.

But there was another recompense to this educational mission, one that would benefit the members of the Institute directly: they were securing their own salvation by giving away their lives in the service of others. The sacrifice involved in their renouncing the cloister for this unforgiving struggle in the world was sure to gain them a place in heaven, near the martyrs of the faith and the missionary priests with whom they worked in recusant England. Indeed, physical and moral suffering, material and emotional deprivation, personal and public humiliation were often the bitter portion of the English Ladies. The 1620s saw a rising tide of opposition to the Institute and later, after the proclamation of the 1631 Bull of suppression, Mary Ward's imprisonment in Munich, placed her followers in even greater turmoil. In a letter to the pope in that year, Ward described these dark times in a poignant passage that brings to life the very wretchedness of the English Ladies' lives at that point. She evoked the harshness of her own condemnation as a heretic and mentioned, as if in passing, that incarceration had brought her to the very gates of death. Yet, she was more concerned with the welfare of her followers. Her condemnation also affected her disciples most cruelly: the stain on her good character, by association, marred the reputations of her followers and her fall was shared by all:

Our Ladies have been mocked by the heretics for having abandoned their fatherland and families; they have been despised by their closest relations; their annual income has been unjustly seized so that in four of our colleges it has been necessary to ask for alms. ${ }^{44}$

Mary Ward bemoaned the injustice of popular and ecclesiastical censure, especially since she envisaged the apostolate as a pathway to the divine. And yet, the very suffering they endured in their apostolate was to be part of its redemptive nature. She believed that the difficulties hindering her Institute's progress, the recurrent attacks against the Ladies' integrity and the general suffering they endured were as nothing compared to the reward God had in store for them. She considered their teaching vocation as the manifestation of their absolute abandonment to the will of God and as a direct conduit towards the salvation of their souls. She once wrote to one of her companions, Mother C. Morgan, assuring her that her work could not fail but ensure her 'lasting crown'. ${ }^{45}$

Thus, the Institute's Ignatian mission was doubly perfect. On the one hand, it strengthened girls' knowledge of God and enabled them to read devotional works. Thus, pupils were fully armed to face the hardships that awaited them in this life, particularly under the repressive English penal laws. On the other hand, this educational mission reaped a second harvest, one that benefited the English Ladies 
directly: by dedicating their lives to teaching and catechizing, they were working towards their own sanctification.

The English Ladies, though they contradicted the decrees of the Council of Trent, were not rebelling against the established order of their Church. On the contrary, when they abandoned the ideal of monastic life and the quietude of private devotion in order to labour in the world, they accepted their vocation as their cross. Their mixed life was their ultimate sacrifice, one in which the apostolate that spearheaded the Counter-Reformation was intertwined with elements of traditional spirituality. Hence, Mary Ward's strong-worded declarations about women's worth and ability in the Church did not equate to her rejection of a tradition she found misogynistic and restrictive. Appealing as it may be, her representation as an ambitious feminist who purposefully exploded the boundaries of female involvement in the Church is an anachronistic misinterpretation of the genesis of the Institute, the active vocation of which found daily nourishment in traditional medieval practices. When the English Ladies abandoned the ideal of monastic life and the serenity of private devotion in order to become evangelists, they embraced the 'mixed' life as their cross. Therefore, in imitation of Christ, the teaching nuns suffered adversity gladly; the stumbling blocks in their path were so many trials of their fortitude, but the French Ursulines and the English Ladies always continued to hope. They had a conviction: like Christ, they were sacrificing themselves to the active life for the glory of God. Like him, they would be rewarded a thousand-fold and gain, through this new form of martyrdom, the sanctification of their souls. In this way, the Ladies undertook the active apostolate as an act of penance, in a subtle adaptation of the medieval values of self-abnegation to the new conditions of the seventeenth-century apostolic drive.

\section{NOTES}

${ }^{1}$ Patrick Collinson, " "Not Sexual in the Ordinary Sense"” in Elizabethan Essays

(London, 1994), p. 127.

${ }^{2}$ Bar Convent Archives (thereafter BCA), B18, Institutum, f. 19.

${ }^{3}$ Ibid., f. 23.

${ }^{4}$ Ibid., f. 22.

${ }^{5}$ M.C.E. Chambers, The Life of Mary Ward, 1585-1645, 2 vols (London, 1882-1885),

vol. 2, p. 27: 'Those who in respect of the fear of persecution [...] I cannot at the first

bring to resolve to be living members of the Catholic Church, I endeavour at least so

to dispose them that understanding and believing the way to salvation, they seldom or unwillingly go to heretical churches'. 
${ }^{6}$ Chambers, Life, vol. 2, p. 28.

${ }^{7}$ BCA, B17, f. 2, Three speeches of our Reverend Mother Chief Superior made at St Omer having been long absent.

${ }^{8}$ Ibid., f. 3.

${ }^{9}$ Westminster Diocesan Archives (thereafter WDA), B 25, f. 56.

${ }^{10}$ Ibid., f. 54.

${ }^{11}$ BCA, C1, Letters against the Jesuitesses, f. 311.

${ }^{12}$ WDA, vol. 16, f. 207. In her article " "Wandering Nuns": The Return of the Institute of the Blessed Virgin Mary to the South of England, 1862-1945', Recusant History 24.3 (1999) 384-96, Sr. M. Gregory Kirkus, IBVM, explores what she calls 'the purposeful mobility' of the members of the Institute in more recent years.

${ }^{13}$ BCA, B5, letter 4 to Mgr Albergati, 1620.

${ }^{14}$ See Jeanne Cover, Love, the Driving Force: Mary Ward's Spirituality and its Significance for Moral Theology (Milwaukee, Wis., 1997); Margaret Littlehales, Mary Ward (1585-1645). A Woman for All Seasons (London, 1974) and Mary Ward, Pilgrim and Mystic (London, 1998),. Note also articles such as Lavinia Byrne, 'Mary Ward's Vision of the Apostolic Religious Life', The Way Supplement 53 (1985) 73 84; Joseph Grisar, 'Mary Ward, 1585-1645', The Month 12.22 (1954) 69-81; and Immolata Wetter, 'Mary Ward's Apostolic Vocation', The Way, supplement 17 (1972) 69-91.

${ }^{15}$ Henriette Peters, Mary Ward: A World in Contemplation, trans. by Helen Butterworth (Leominster, 1994), pp. 44-54.

${ }^{16}$ Adam Hamilton, The Chronicle of the English Augustinian Canonesses of the Lateran, at St Monica's in Louvain, 1548 to 1625 (Edinburgh, 1904), p. 180. See also Roland Connelly, Women of the Catholic Resistance (Durham, 1997), pp.191-93. 
${ }^{17}$ Painted Life, panel 9.

${ }^{18}$ BCA, B4, autobiographical notes, transcribed in Emmanuel Orchard, Till God Will:

Mary Ward through her Writings (London, 1985), p.10.

${ }^{19}$ BCA, B18, Schola Beatae Mariae, item 54.

${ }^{20}$ BCA, B18, Ratio Instituti, f. 16.

${ }^{21}$ BCA, B5, letter 4 to Nuncio Albergati, 1620 (italics mine).

${ }^{22}$ BCA, box 4, necrologies, f. 4.

${ }^{23}$ Ibid., f. 15 .

${ }^{24}$ BCA, B18, Schola Beatae Mariae, item 14.

${ }^{25}$ BCA, B9, notes written during the Spiritual Exercises, 1612-14, resolution 27.

${ }^{26}$ BCA, A12, A Briefe Relation of the Holy Life and Happy Death of our Dearest

Mother, ff.15-16. This is a posthumous biography, written jointly by Mary Poyntz

and Winefred Wigmore, Mary Ward's closest two followers, c. 1650.

${ }^{27}$ BCA, B9, notes written during the Spiritual Exercises, 1612-14, resolution 5.

${ }^{28}$ BCA, B9, retreat notes, April 1618.

${ }^{29}$ BCA, box 4, necrologies, f. 17.

${ }^{30}$ The Painted Life, panel 10.

${ }^{31}$ See, inter alia, R. Blumenfeld-Kosinski and T. Szell (eds.) Images of Sainthood in

Medieval Europe (Ithaca, NY, 1991); Barbara Newman, From Virile Woman to

WomanChrist: Studies in Medieval Religion and Literature (Philadelphia, Penn.,

1995); Elizabeth Petroff, Body and Soul: Essays on Medieval Women Mysticism (New

York, 1994); Diane Watt, Medieval Women in their Communities (Cardiff, 1997).

${ }^{32}$ BCA, B5, letter 4 to Mgr Albergati, 1620.

${ }^{33}$ Ibid.

${ }^{34}$ Ibid. 
${ }^{35}$ BCA, B18, Ratio Instituti, f.5, my italics

${ }^{36} \mathrm{BCA}$, box 4 , necrologies, f. 15 .

${ }^{37}$ BCA, B18, Institutum, f. 20.

${ }^{38}$ BCA, B9, notes written during the Spiritual Exercises, 1612-14, resolution 35.

${ }^{39}$ BCA, B9, Various Papers, 'The Loneliness', f. 34.

${ }^{40}$ BCA, B12, Briefe Relation.

${ }^{41}$ The Painted Life, panel 30.

${ }^{42}$ The Saints represented are Benedict, Pachomius, Francis of Assisi, Dominic, Clare,

Bridget, Scholastica and Teresa of Àvila.

${ }^{43}$ Peters, Mary Ward, pp. 256-57.

${ }^{44}$ BCA, B5, letter 86, f. 93 d.

${ }^{45}$ BCA, B5, letter 44, f. 71. 